\title{
Pengenalan Instalasi Listrik yang Aman Kepada Siswa-Siswi SMPN 7 Mataram
}

\author{
Ni Made Seniari ${ }^{1}$, Rosmaliati ${ }^{2}$, Supriyatna ${ }^{3}$, Abdul Natsir $^{4}$, Ida Ayu Sri Adnyani ${ }^{4}$, Sabar Nababan $^{5}$ \\ 1,2,3,4,5 Jurusan Teknik Elektro, Fakultas Teknik Universitas Mataram, Nusa Tenggara Barat, Indonesia
}

\begin{abstract}
Understanding of electrical installation and the use of electrical equipment that is proper and safe, has a big contribution to the safety and security around us. The introduction of safe electrical installations according to the Indonesian National Standard, namely the General Requirements for Electrical Installations (SNI: PUIL 2011) needs to be disseminated to the public from an early age. The problems were: (1) Socialization of electrical installations is less socialized to the wider community, (2) Socialization of SNI PUIL 2011 is less socialized by related parties, (3) There is no special curriculum that provides practical skills to junior high school students regarding safe electrical installations. External targets are students: (1) Can recognize the components of simple electrical installations in their homes, (2) Understand the functions and workings of installation components, (3) Understand the procedures for installing electrical installations, (4) Be able to plan installation installations electricity. The methods used were (1) lectures on understanding the importance of safe electrical installations, the functions and workings of installation components, (2) demonstrations using electrical installation module boards, (3) Questions and answers and discussions. The results achieved included students: (1) Understanding of simple electrical installations in their homes, (2) Understanding of electrical installation procedures and planning, (3) Being able to plan installations.
\end{abstract}

Keywords: Introduction Of Electrical Installations

\section{PENDAHULUAN}

Energi listrik merupakan sesuatu hal yang sangat dibutuhkan dan bermanfaat dalam kehidupan manusia. Oleh karena itu, tanpa energi listrik manusia tidak bisa melakukan aktifitasnya sehari-hari seperti memasak, menonton, bekerja di perkantoran, industri dan lain sebagainya. Selain bermanfaat listrik juga dapat berbahaya bagi kehidupan manusia, apabila di dalam penggunaannya manusia lalai dan mengabaikan keselamatan sendiri beserta orang-orang disekitarnya.

Pemahaman tentang cara menggunakan peralatan listrik di sekitar kita memiliki kontribusi yang besar terhadap keselamatan dan keamanan disekitar kita. Berdasarkan hal tersebut penting kiranya melalui pengabdian kepada masyarakat kita mulai mensosialisasikan dan memperkenalkan instalasi yang aman kepada siswa-siswi di SMPN 7 Mataram. Pelaksanaan pengabdian kepada masyarakat dengan sasaran adalahsiswa siswi SMPN 7 Mataram yang sedang duduk dikelas VIII..Pelaksanaan Kegiatan Pengabdian Masyarakat ini di ikut ioleh kelas VIII, siswa siswi SMPN 7 Mataran, yang di wakili oleh 7 orang masing-masing kelas. Jumlah total siswa siswi yang terlibat dalam kegiatan ini berjumlah 38 orang, denga nseorang guru pendamping.

Materi yang di sajikan berupa pengenalan instalasi listrik sederhana yang aman sesuai Standar Nasional Indonesia 2011(SNI), tentang Pesyaratan Umum Instalasi Listrik (PUIL). Materi ini di sampaikan bertujuan agar siswa siswi SMP memiliki pemahaman yang baik dan benar tentang peralatan instalasi listrikyang berada di rumah mereka masing-masing sudah digunakan dengan aman. Diharapkan mereka dapat menilai apakah instalasi listrik di rumahnya sudah aman atau tidak.Pelaksanaan kegiatan diperlihatkan pada Gambar 1.

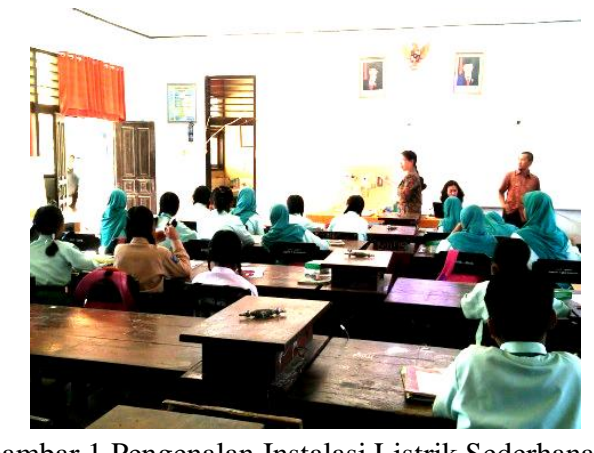

Gambar 1.Pengenalan Instalasi Listrik Sederhana 
Pemasangan instalasi listrik yang aman menggunakan komponen-komponen ataupun peralatan listrik yang berstandar SNI, tidak harus mahal atau memiliki merk tertentu, yang terpenting terdapat logo SNI pada produk. Adapun komponen-komponen instalasi listrik tersebut seperti kabel, stop kontak,saklar, rumah lampu dan lain sebagainya.

Pemilihan kabel listrik yang sesuai dengan SNI seperti salah satu contohnya kabel berdiameter 2,5 $\mathrm{mm}$ yang tergolong cukup kuat untuk dialiri listrik hingga daya 5.000 watt. Biasanya kabel ini digunakan pada rumah dengan luas di bawah 70 meter persegi. Untuk kebutuhan listrik pada peralatan rumah tangga seperti lampu dengan daya di bawah 100 watt dapat menggunakan kabel berdiameter $1,5 \mathrm{~mm}$. Kabel berdiameter 1,5 $\mathrm{mm}$ ini aman digunakan untuk jalur stop kontak yang nantinya dapat di pergunakan untuk peralatan listrik yang memiliki daya rendah seperti charge smartphone.

\section{METODE YANG DIGUNAKAN}

a. Metode yang dipergunakan dalam pelaksanaan pengabdian kepada masyarakat adalah pendekatan ilmiah dan praktis secara sistematis dengan melakukan pemaparan dan pengenalan materi bahan-bahan listrik, metode diskusi (tanya jawab) dilakukan selama proses pemaparan berlangsung.

b. Evaluasi kegiatan: membuat kuis berhdiah flasdisk bagi yang menjawab dengan benar pertanyaan yang diajukan pemateri untuk mengetahui sejauh mana siswa siswi memahami materi yang telah di berikan oleh narasumber.

\section{PELAKSANAAN DAN HASIL KEGIATAN}

Pelaksanakan dilakukan di Laboratorium SMPN 7 Mataram dengan metode ceramah tentang (Gambar 2):

a. Pengenalan alat instalasi listrik,

b. Pengenalan bahan utama dan bahan pembantu instalasi listrik,

c. Fungsi dari masing-masing bahan,

d. Carakerja masing-masing alat, e. Pengawatan.

f. Tata tertib danstandar pemasangan instalasi listrik,

g. Simbul gambar instalasi

h. Cara membaca simbul komponen-komponen instalasi.

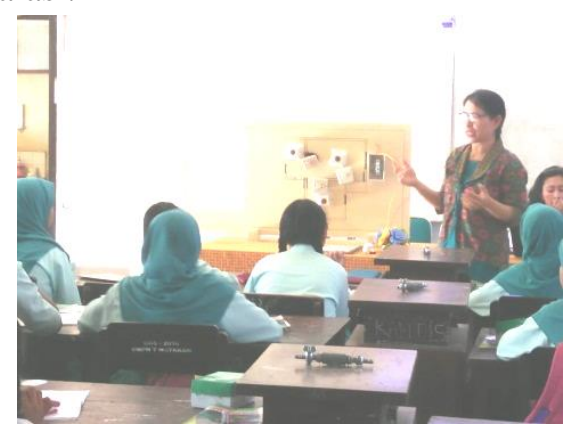

Gambar2. Pemaparan materi

Kegiatan pengabdian kepada masyarakat ini diharapkan dapat membantu siswa, pihak sekolah dan Diknas dalam menerapkan kurikulum 2013 secara total. Dengan penyampaian matri pelajaran dari tenaga pengajar tamu (dalam hal ini dosendosen Jurusan Teknik Elektro Unram), diharapkan ada suasana pembelajaran penyegaran, tidak monoton, tidak membosankan dan kreatifitas siswa difasilitasi. Dalam hal ini siswa juga semakin terlatih mengamati fenomena yang sedang dipraktekkan, meningkatkan kreatifitasnya, meningkatkan keberaniannya untuk memberi pendapat, saran dan melakukan diskusi-diskusi ringan yang dapat menggali penalaran logika berfikir siswa. Berangkat dari hal-hal tersebut diharapkan bahwa pelaksanaan kurikulum 2013 dapat meningkatkan pencapaian sasaran secara terus menerus dan berkesinambungan.

Adapun tahapan pemberian materi sebagai berikut:

Langkah pertama yaitu: persiapan membuat gambar denah rumah, gamba rrangkaian listrik dan pengawatan, dengan gambar denah perencanaan diambil contoh padarumah typ 40 dan $120 \mathrm{~m}^{2}$ dapat dilihat pada Gambar 3. 


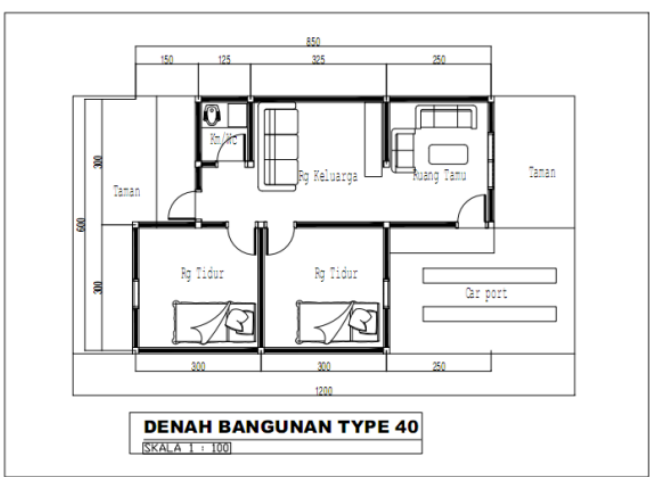

Gambar3.Denahbangunan type $40 \mathrm{~m}^{2}$

Langkah kedua: Persiapan Papan Module :Papan modul yang digunakan dengan lembar triplek berkaki (sehingga modul mampu berdiri). Diawali dengan module rangkaian yang sangat sederhana yaitu pemasangan MCB, stop kontak untuk rangkaian seri dan pararel. Tahap berikutnya dilanjutkan dengan pemasangan pada module rumah sederhana type $40 \mathrm{~m} 2$ yang hanya terdiri dari satu group. Selanjutnya di lakukan demo pemasangan instalasi dengan papan module yang tersedia. Peserta (siswa siswi SMPN 7) menyimak pemasangan instalasi pada papan modul, dengan alat, bahan, gambar denah yang telah disediakan (Gambar 4).

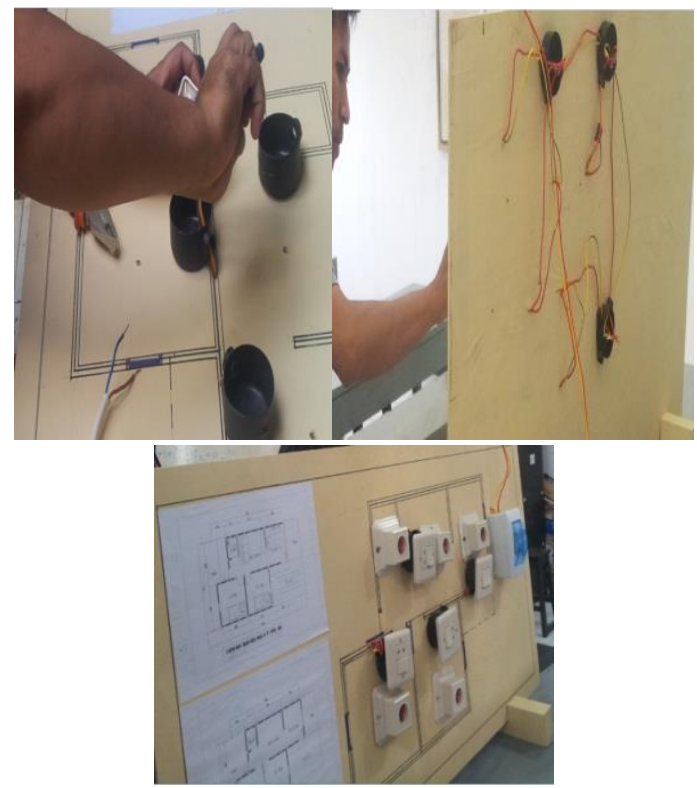

Gambar4.Modul Demo instalasilistrik

Tingkat keberhasilan pelaksanaan pengabdian ini dievaluasi berdasarkan indikator-indikator sebagai berikut :

a. Adanya dukungan penuh dari pihak sekolah yang bersedia memberi ijin, mengalokasikan waktu dan bahkan memodifikasi jadwal pembelajaran.

b. Keaktifan siswa-siswi dalam mengikuti kegiatan pengabdian ini

c. Adanya diskusi-diskusi kecil yang dapat membantu siswa dalam memahami kegiatan me.buat instalasi listrik sederhana.

d. Adanya permintaan siswa-siswi untuk diberi pengetahuan tentang teknik-teknik rangkaian yang lebih kompleks serta adanya keinginan untuk mengukur arus dan tegangan listrik pada masing-masing percabangan rangkaian.

e. Adanya perwakilan ucapan trimakasih pihak sekolah kepada tim penyuluh, yang juga menyampaikan bahwa sistem pebelajaran tersebut sangat disukai oleh siswa, membuat suasana belajar sangat menarik dan tidak membosankan.

f. Adanya penyampaian siswa-siswi bahwa mereka akan mencoba lagi di luar sekolah dengan rangkaian yang lebih bervariasi dan lampu bolham yang lebih banyak.

\section{KESIMPULAN}

Hasil pelaksanaan pengabdian masyarakat kemitraan, dapat ditarik kesimpulan :siswa siswi sangat antusias mengikuti setiap penjelasan dan peragaan dari setiap proses pelaksanaan kegiatan cara-cara aman untuk membuat instalasi listrik sederhana. Dengan peragaan dan penjelasan sistem kerja komponen dan alat instalasi listrik, siswasiswi mendapat pengetahuan baru yang lebih praktis, detail dan sederhana.

\section{DAFTAR PUSTAKA}

Indra., Z, dan Kamil, I., 2011, “Analisis Sistem Instalasi Listrik Rumah Tinggal danGedunguntuk Mencegah Bahaya Kebakaran, "Jurnal Ilmiah Elite Elektro,Vol.2, No.1, Maret 2011:40-44

Mulianan,R.Y.2012, “Dasar-Dasar Instalasi Listrik",https://rohmatyusufmuliyana.wordpress .com/elektro/dasar-\%E2\%80\%93-dasarinstalasi-listrik/ Diakses 20-4-2020. 
Suhinal, El. 2016,"Instalasi Listrik Rumah Dengan Memahami

Wiring

Diagram",https://www.listrik-

praktis.com/2016/01/belajar-instalasi-dasar-

rumah-memahami- wiring-diagram.html.

diakses 20-4-2018

Standar Nasional Indonesia (SNI 0225:2001) :

Persyaratan Umum Instalasi Listrik 2011 (PUIL

2011), Badan Standarisasi Nasional 